\title{
ATMOSFERA MODIFICADA E CONTROLE DE ETILENO PARA BANANAS 'PRATA-ANÃ' CULTIVADAS NA AMAZÔNIA SETENTRIONAL BRASILEIRA ${ }^{1}$
}

\author{
MARCOS ANDRÉ DE SOUZA PRILL², LEANDRO CAMARGO NEVES 3 , \\ JÉSSICA MILANEZ TOSIN ${ }^{4}$, EDVAN ALVES CHAGAS
}

RESUMO-O presente trabalho teve por objetivo avaliar o efeito da atmosfera modificada (AM) pelo uso de embalagem plástica de polietileno de baixa densidade (PEBD), do vácuo e da adsorção de etileno, visando à manutenção da qualidade das bananas 'Prata-Anã' produzidas em Roraima. As análises foram realizadas em intervalos de 5 dias após a colheita, até 35 dias de armazenamento refrigerado (AR). Verificou-se que os frutos submetidos a embalagem de PEBD apresentaram as menores perdas de massa fresca quando comparados aos demais. Da mesma forma, os frutos embalados na presença do adsorvedor de etileno obtiveram a melhor manutenção na coloração da casca, atraso temporal, do pico climatérico, assim como o retardamento na degradação do amido, os menores incrementos de sólidos solúveis e acidez titulável, as menores concentrações de etileno nos interiores das embalagens e atraso temporal e a diminuição da atividade enzimática. Isso, possivelmente, proporcionou os maiores teores de pectina total e solúvel ao final do período experimental. A combinação do uso da embalagem de PEBD com o sachê de permanganato de potássio $\left(\mathrm{KMnO}_{4}\right)$ resultou no retardamento do processo de maturação dos frutos de banana 'Prata-Anã', quando armazenada a $12{ }^{\circ} \mathrm{C}$. Pode-se atribuir esse efeito benéfico à presença do sachê na adsorção de etileno e, consequentemente, na ação do etileno no amadurecimento dos frutos, retardando a senescência das bananas 'Prata-Anã'.

Termos de indexação: armazenamento refrigerado, conservação, Musa AAB, qualidade.

\section{ATMOSPHERIC MODIFICATION AND ETHYLENE'S CONTROL IN POSTHAVERST, FOR 'PRATA-ANÃ' BANANAS CULTIVATED IN THE SETENTRIONAL BRAZILIAN AMAZON}

\begin{abstract}
This present study aimed to evaluate the effect of modified atmosphere (MA) by the use of plastic packaging for low density polyethylene (LDPE), the vacuum and the adsorption of ethylene, aiming the maintenance of the quality of bananas 'Prata Anã' cultived in Roraima.. Analyses were performed each 5 days after harvest, up to 35 days. It was verified that the fruit under LDPE bags showed the lowest losses of fresh weight when compared to the others. Likewise, as the fruits packed in the presence of ethylene adsorption sachet had the best maintenance in the color peel, delay of the climacteric peak, as the delay in the starch degradation, lowest increments of soluble solids and titratable acidity, the lowest concentration of ethylene inside the LDPE bags and delay and decrease of enzyme activity. The combination of the use of LDPE bags with the sachet of potassium permanganate $(\mathrm{KMnO} 4)$ resulted in the delay of ripening fruits of bananas 'Prata Anã', when stored at $12{ }^{\circ} \mathrm{C}$. It can be attributed this beneficial effect by the presence of the sachet in the adsorption of ethylene and, consequently, in the action of ethylene in the fruit ripening, delaying the senescence of bananas 'Prata Anã'.
\end{abstract}

Index terms: cold storage, conservation, Musa sp., quality.

\footnotetext{
1(Trabalho 008-12). Recebido em: 02-01-2012. Aceito para publicação em: 22-11-2012.

${ }^{2}$ Mestrando em Agronomia (POSAGRO), CCA/UFRR, Km 12 BR 174 s/nº, CEP 69301-970, Boa Vista/RR. E-mails: marcosprill@ bol.com.br

${ }^{3}$ Prof. Dr. do Depto de Fitotecnia, CCA/UFRR, Km 12 BR 174 s/nº CEP 69301-970, Boa Vista/RR. E-mail: rapelbtu@gmail.com. ${ }^{4}$ Acadêmica de Agronomia, bolsistas CNPq, CCA/UFRR, Km 12 BR 174 s/nº, CEP 69301-970, Boa Vista/RR. E-mail: jessica.mtosin@hotmail.com

${ }^{5}$ EMBRAPA - Pesquisador Embrapa Roraima, Km 08, BR 174 s/nº, CEP 69301-970, Boa Vista/RR echagas@cpafrr.embrapa.br
} 


\section{INTRODUÇÃO}

O Brasil é o terceiro maior produtor de banana, responsável por $8,7 \%$ do volume produzido, sendo superado pela Índia e China, responsáveis por $26,8 \%$ e $9,0 \%$ do volume produzido, respectivamente. Na safra brasileira de 2009, a área plantada foi de 483.562 hectares, área colhida de 479.614 hectares e produção de 6.783 .482 toneladas, com rendimento de $12.87 \mathrm{~kg} / \mathrm{ha}$ (SARMENTO et al., 2012). Em Roraima, existe produção de bananas em todos os municípios, onde cerca de $75 \%$ da produção se destina ao consumo externo (dados não publicados). Porém, como em todo o Brasil, a qualidade é comprometida desde a colheita pela falta de técnicas adequadas à manutenção da qualidade dos frutos (NOGUEIRA et al., 2007).

A banana é considerada como fruto climatérico, altamente perecível, apresentando elevada taxa respiratória e produção de etileno que desencadeiam rapidamente o amadurecimento. $\mathrm{O}$ etileno, composto orgânico volátil, participa diretamente das mudanças bioquímicas e fisiológicas relacionadas ao amadurecimento dos frutos, como, por exemplo, as alterações na coloração, no sabor, na textura, na composição de açúcares redutores e na produção de substâncias voláteis (PEREIRA et al., 2008). A respiração, combinada com outros fatores, principalmente ambientais, como a temperatura e umidade relativa, acelera certos processos, como a transpiração e a produção de etileno, que reduzem a vida útil do fruto devido à perda de qualidade e à rápida deterioração (FINGER et al., 1995).

Como mencionado, a suscetibilidade à senescência, aliada à elevada sensibilidade a danos mecânicos, impede a comercialização dos frutos em locais distantes das áreas produtivas, principalmente quando não se utiliza cadeia do frio (SALES et al., 2004). Dentre outras, as alternativas para diminuição das perdas e da redução acelerada da qualidade são o uso do armazenamento refrigerado (AR) e da AM, da tecnologia de inibição da ação do etileno, podendo ser aplicadas de maneira isolada ou combinadas entre si (NEVES et al., 2008). O AR é essencial para tornar lenta a deterioração química, física e fisiológica dos produtos frescos (PRILL et al., 2012). Associado ou não ao $\mathrm{AR}$, pode-se utilizar o polietileno de baixa densidade (PEBD) como embalagem, pois é um dos filmes que têm sido utilizados para proporcionar a AM, apresentando permeabilidade seletiva aos gases emitidos durante a estocagem de frutos e minimizando também a transpiração (PINTO et al., 2006). Com o objetivo de potencializar os efeitos no retardamento do metabolismo pós-colheita, pode-se associar esses métodos ao sistema de inibição do etileno. Dentre esses, o sachê adsorvedor de etileno, que oxida o etileno liberado pelo fruto durante o amadurecimento, prolongando a fase pré-climatérica e a vida pós-colheita (SILVA et al., 2009).

Diante do exposto, o presente trabalho teve por objetivo avaliar o efeito da AM pelo uso de embalagem plástica de PEBD, do vácuo e da adsorção de etileno, visando à manutenção da qualidade das bananas 'Prata-Anã' produzidas em Roraima.

\section{MATERIAL E MÉTODOS}

O experimento foi realizado com frutos de bananeira 'Prata-Anã', no período de janeiro a fevereiro de 2010, colhidos na empresa Roraima Agrofrutas (latitude $2^{\circ} 50^{\prime} 06^{\prime \prime} \mathrm{N}$ e longitude $60^{\circ} 40^{\prime} 28^{\prime \prime} \mathrm{W}$ ). As análises foram realizadas no Laboratório de Tecnologia de Alimentos (LTA), da Universidade Federal de Roraima (UFRR).

Após colhidos, os cachos foram transportados para a packinghouse da empresa Roraima Agrofrutas, onde passaram por pré-limpeza, eliminando-se a ráquis. Em seguida, realizou-se o pré-resfriamento a $20 \pm 2{ }^{\circ} \mathrm{C}$ por 30 minutos (imersão em tanque com água, sulfato de alumínio e cloreto de cálcio a $2 \%$ ) e a despalma. Os frutos foram então transportados em caixas plásticas de $20 \mathrm{~kg}$ até o LTA, onde foram imersos em solução de hipoclorito de sódio a 2,5\% $\mathrm{L}^{-1}$ de água, por 10 minutos. O enxágue e a secagem dos frutos foram realizados ao ar atmosférico do $\operatorname{LTA}\left(22 \pm 1{ }^{\circ} \mathrm{C}\right.$ e $75 \pm 3 \%$ de U.R.), por 30 minutos.

Os frutos foram uniformizados em buquês (de 3 a 5 dedos) apresentando, em média, $447 \pm 50 \mathrm{~g}$ de massa fresca, medindo de $0,16 \pm 0,02 \mathrm{~m}$ de comprimento e $0,133 \pm 0,02 \mathrm{~m}$ de diâmetro, e a coloração 1, na escala de Von Loesecke (1950), adotada pela CEAGESP (2006), sendo selecionados e padronizados pelo tamanho e pela ausência de danos/defeitos visuais. Cada buquê constituiu-se numa unidade amostral. Foram realizadas análises preliminares, visando-se a caracterizar as bananas recém-colhidas, verificando-se então o $\mathrm{pH}$ médio de 5,50, SS médio de 3,55 ${ }^{\circ}$ Brix e AT média de 2,38\% de ácido málico $100 \mathrm{~g}^{-1}$ de polpa. Os tratamentos foram assim dispostos: T1-Controle (sem embalagem, sistema de adsorção de etileno nem vácuo); T2-Embalagem de polietileno de baixa densidade (PEBD), com 0,010 $\mathrm{mm}$ de espessura (único lado), área de permeabilidade de $805 \mathrm{~cm}^{3}$, taxa de permeabilidade a oxigênio $\left(\mathrm{TPO}_{2}\right)$ de $11.234 \mathrm{~cm}^{3} \mathrm{~m}^{-2} \mathrm{~d}^{-1} \mathrm{e}$ taxa de permeabilidade a gás carbônico $\left(\mathrm{TPCO}_{2}\right)$ de $36.705 \mathrm{~cm}^{3} \mathrm{~m}^{-2} \mathrm{~d}^{-1}$; T3PEBD + adsorvedor de etileno (sachê de $10 \mathrm{~g}$, marca 
Always Fresh ${ }^{\circledR}$, do fabricante Soloeste); T4-PEBD + vácuo (-600 mmHg); e T5-PEBD + adsorvedor de etileno + vácuo. Após a aplicação dos tratamentos, as unidades amostrais - U.A. (buquês), foram armazenadas em câmara frigorífica a $12 \pm 1^{\circ} \mathrm{C}$ e U.R. de $93 \pm 2 \%$, durante 35 dias. Os dados analíticos foram coletados em triplicata, em intervalos de 5 dias a partir da data da colheita, até os 35 dias de AR. Sempre 12 horas antes das análises, os frutos eram retirados do $\mathrm{AR}$, visando à elevação da temperatura dos frutos até o equilíbrio com o ambiente do LTA $\left(22 \pm 1{ }^{\circ} \mathrm{C}\right.$ e $75 \pm 3 \%$ de U.R.). Em cada dia de análise, foram avaliados os seguintes parâmetros:

1 - Perda de massa fresca: quantificada pela variação percentual (\%) da massa fresca de cada U.A. no decorrer do experimento, em cada período de análise, em comparação à massa fresca inicial da unidade experimental na instalação do experimento.

2 - Coloração: avaliada quanto à coloração da casca dos buquês, seguindo a escala subjetiva de valores de Von Loesecke (1950).

3 - Concentração de etileno e $\mathrm{CO}_{2}$ : A concentração de etileno foi quantificada por cromatografia gasosa, utilizando cromatógrafo a gás marca Varian $\AA$, modelo 3300, equipado com coluna de aço inox 1/8", preparado com Porapak ${ }^{\circledR} \mathrm{N}$ e detector de ionização de chama. A concentração de $\mathrm{CO}_{2}$ foi quantificada em cromatógrafo Shimadzu ${ }^{\circledR}$ CR 950 , equipado com sistema de detecção por condutividade térmica. Foram utilizados como padrões soluções de etileno e $\mathrm{CO}_{2}$ a $100 \mathrm{mg} \mathrm{Kg}^{-1}$ e 5\%, respectivamente, para cada gás. Os resultados foram expressos em $\mu \mathrm{l}$ de etileno $\mathrm{Kg}^{-1} \mathrm{~h}^{-1}$ e mg de $\mathrm{CO}_{2} \mathrm{Kg}^{-1} \mathrm{~h}^{-1}$.

4 - Acidez titulável (AT): determinada por titulometria de neutralização, pela titulação de $10 \mathrm{~g}$ de polpa triturada, homogeneizada e diluída para 100 $\mathrm{mL}$ em água destilada, com solução padronizada de hidróxido de sódio a $0,1 \mathrm{~N}$, com ponto de viragem no $\mathrm{pH} 8,2$. Os resultados foram expressos em $\%$ de ácido málico $100 \mathrm{~g}^{-1}$ de polpa (IAL, 2005).

5 -Atividade enzimática: pectinametilesterase (PME) foi determinada segundo Jen e Robinson (1984), em que se analisou a capacidade da enzima em catalisar a desmetilação de pectina correspondente a $1 \mu \mathrm{mol}$ de $\mathrm{NaOH}$ por minuto, nas condições de ensaio. Os resultados foram expressos em $\mu \mathrm{mol}$ de $\mathrm{NaOH} \mathrm{g}{ }^{-1} \mathrm{~min}^{-1}$. A enzima poligalacturonase (PG) foi determinada segundo Pressey e Avants (1973), em que se avaliou a capacidade da enzima em catalisar a formação de de 1 ๆmol de açúcar redutor por minuto, por grama de amostra. Os resultados foram expressos em $\eta$ mol de aç.red. $\mathrm{g}^{-1} \mathrm{~min}^{-1}$.

6 - Pectina total e solúvel: extraídas segundo McCready e McCoomb (1952) e determinadas colo- rimetricamente pela reação com carbazol, segundo Bitter e Muir (1962). Os teores foram expressos em porcentagem (\%) de ácido galacturônico $100 \mathrm{~g}^{-1} \mathrm{de}$ polpa.

7 - Sólidos Solúveis (SS): determinados por refratometria, através de refratômetro portátil, modelo - RT 30ATC. Os resultados foram expressos em ${ }^{\circ}$ Brix (IAL, 2005);

8 -Amido: Pesou-se $1 \mathrm{~g}$ de amostra, previamente seca em erlenmeyer de $250 \mathrm{~mL}$. Adicionaram-se a essa $50 \mathrm{~mL}$ de ácido clorídrico $(\mathrm{HCl})$ a $1 \mathrm{M}$ (8,5 mL de $\mathrm{HCl}$ em $1 \mathrm{~L}$ de água destilada). Os frascos contendo as amostras foram colocados em recipiente plástico para micro-ondas com água no fundo suficiente para evitar secar. Os erlenmeyers permaneceram em micro-ondas durante 20 minutos na potência máxima. Após, o amido transformou-se em açúcares, e algumas gotas foram retiradas para o teste com Lugol. A seguir, a amostra foi neutralizada com $\mathrm{NaOH}$ a $10 \%$, usando- se 3 gotas de fenilfetaleína como indicador até a coloração rósea. Os resultados foram expressos em $\mathrm{mg}$ de glicose 100 $\mathrm{g}^{-1}$ de polpa (IAL, 2005).

$\mathrm{O}$ experimento foi conduzido em delineamento inteiramente casualizado (DIC), com o esquema fatorial $5 \times 7$ (tipos de acondicionamento $\mathrm{x}$ dias de análises), com 3 repetições, e cada repetição composta por 2 unidades amostrais. Feita a análise exploratória dos dados, constatou-se que os mesmos seguiam distribuição normal, os erros eram independentes e apresentavam homocedasticidade. Assim, os dados foram submetidos à análise de variância pelo teste $\mathrm{F}$, e a comparação de médias, efetuada pelo teste de Tukey, a 5\% de probabilidade estatística.

\section{RESULTADOS E DISCUSSÕES}

Os frutos armazenados sem a embalagem plástica foram os que apresentaram as maiores perdas de massa fresca (Figura 1), com significativa diferença estatística quanto aos demais tratamentos. Detectou-se também o comportamento climatérico padrão normal nos frutos embalados em PEBD ao longo do tempo, ou seja, sem qualquer sinal de anaerobiose, evidenciando-se que os mesmos estavam em pleno metabolismo respiratório, levando-se em consideração o estádio de maturidade dos frutos em cada um dos tratamentos testados.

Para os frutos-controle, observou-se, já a partir dos 10 dias de AR, perdas de massa fresca superiores a $10 \%$, o que supostamente comprometeu, precocemente, a qualidade visual desses frutos. Contudo, as menores perdas constatadas nas bananas acondicionadas nos filmes plásticos de PEBD, em 
especial nos frutos submetidos ao sachê adsorvedor e ao vácuo, apresentando médias não superiores a $5,05 \%$ ao longo do período experimental, o que pode ser caracterizado como positivo do ponto de vista comercial.

Silva et al. (2006), trabalhando com amadurecimento de bananas 'Prata' climatizadas em diferentes dias após a colheita, observaram perdas graduais de massa fresca nos frutos para os 3 períodos de climatização testados. Esses mesmos autores relataram que essas perdas foram tanto maiores quanto maiores foram os graus de amadurecimento dos frutos, ou seja, o mesmo observado neste trabalho, porém com maior intensidade nos frutos acondicionados sem a presença do sachê adsorvedor ao final do experimento. Contudo, aos 30 dias de AR, a combinação do sachê adsorvedor e da embalagem plástica, associada ou não ao vácuo, apresentou valores de perda de massa estatisticamente inferiores aos demais tratamentos. Isso revela a desaceleração na velocidade do amadurecimento desses frutos, fato esse constatado pela atividade respiratória estatisticamente superior dos frutos acondicionados na presença do adsorvedor de etileno. Assim, como consequência dessa desaceleração, verificou-se também a diminuição da perda de massa fresca nos frutos submetidos ao sistema de adsorção de etileno nesse período.

O efeito metabólico observado pelo uso das embalagens de PEBD deveu-se à permeabilidade reduzida do filme plástico ao meio externo, diminuindo por sua vez as trocas gasosas. Segundo Jerônimo et al. (2007), o uso de embalagens plásticas associadas ao AR, na conservação pós-colheita de mangas, prolongou o período de conservação pós-colheita dos frutos. Nesse mesmo estudo, a utilização da embalagem plástica reduziu os danos oxidativos ocasionados pela respiração e transpiração, como a perda de massa fresca e a mudança na aparência dos frutos, o mesmo ocorrido no presente trabalho. Portanto, o uso do PEBD proporcionou o desenvolvimento da AM favorável que limitou as trocas gasosas entre os frutos e o ambiente externo, fazendo com que houvesse maior concentração de $\mathrm{CO}_{2}$ (Figura 3a) e etileno (Figura 3b) no interior das embalagens, proporcionando a melhor manutenção da qualidade desses frutos durante os 30 dias de AR.

As variações na coloração da casca das bananas (Figura 2), ocorridas durante o amadurecimento dos frutos, possivelmente, estariam relacionadas com processos degradativos relacionados ao metabolismo respiratório dos frutos. Nesse sentido, como descrito na metodologia, os tratamentos foram constituídos com frutos no nível 1 (VON
LOESECKE, 1950), e alguns desses, principalmente os não expostos ao sachê adsorvedor de etileno, evoluíram para a coloração próxima ao nível 7 , ao final do experimento. Segundo Silva et al. (2006), durante o amadurecimento de bananas, a degradação da coloração verde é intensa, ficando visível a preexistência dos pigmentos carotenoides, de coloração amarelada a alaranjada. Contudo, a velocidade do desverdecimento pôde aqui ser considerada como indicativo válido da constatação da velocidade do amadurecimento dos frutos (NOGUEIRA et al., 2007) e, consequentemente, do potencial de conservação das bananas 'Prata-Anã'.

Nesse sentido, durante o período de AR, observou-se influência significativa dos tratamentos testados, provando que, mesmo sob condições de AM mais a presença do sachê adsorvedor, ocorreu a evolução na coloração. Porém, a velocidade metabólica desse processo aconteceu de forma mais lenta nos frutos expostos ao sachê adsorvedor de etileno. Por outro lado, somente se verificaram diferenças significativas entre os tratamentos a partir dos 15 dias, intensificando-se aos 25; 30 e 35 dias de experimento, ou seja, próximos ao período final de comercialização dos frutos. Esses resultados permitiram a pressuposição de que o metabolismo respiratório das bananas se torna mais intenso após 15 dias de AR nas condições aqui testadas.

Desta forma, atribuiu-se ao sachê adsorvedor um efeito temporal, principalmente quanto à redução do etileno livre observada no interior das embalagens (Figura 4b). Isso, supostamente, refletiu com maior intensidade somente a partir dos 25 dias de AR, observando então a diminuição do efeito desse fitorregulador no desverdecimento dos frutos. Brackmann et al. (2006), testando o efeito do adsorvedor de etileno contendo permanganato de potássio em bananas 'Prata', verificaram que a coloração da casca ficou mais esverdecida nos frutos armazenados em AM com a adsorção de etileno, quando em comparação aos frutos refrigerados e expostos somente ao sistema de adsorção de etileno. Esses resultados podem ser relacionados ao efeito da AM na diminuição da atividade das enzimas e dos sistemas oxidantes, em função dos elevados níveis de $\mathrm{CO}_{2}$ detectados nas embalagens. Tais observações corroboraram as discussões apresentadas, haja vista a menor velocidade das reações bioquímicas nos frutos dos tratamentos com o PEBD e a adsorção de etileno.

Na Figura 3a, verificou-se que até os 15 dias de AR não foram observadas diferenças estatísticas entre os tratamentos para o parâmetro concentração de $\mathrm{CO}_{2}$. Esse resultado permitiu o entendimento visual quanto ao incremento da velocidade metabólica que 
ocasionou as transformações ocorridas nos frutos durante o amadurecimento, como observado nas análises enzimáticas (Figuras 5a e 5b), de SS (Figura 7) e de AT (Figura 4). Dessa forma, aos 20 dias de AR, verificaram-se as maiores concentrações de $\mathrm{CO}_{2}$ nos frutos do tratamento-controle, caracterizando para esse ponto o pico climatérico dos mesmos. Aos 25 dias, por outro lado, verificou-se a menor concentração de $\mathrm{CO}_{2}$ nesses frutos. Tal comportamento pode ser explicado pelo fato de os frutos desse tratamento estarem em senescência. Fato esse caracterizado pela frequente diminuição da concentração do $\mathrm{CO}_{2}$ até o final do experimento, como também pela redução dos teores de amido (Figura 8), que durante o senescência dos frutos, após a conversão em açúcares simples, são utilizados como substrato energético. Esse fenômeno metabólico foi retardado pela presença do sachê adsorvedor, visto que as maiores concentrações de $\mathrm{CO}_{2}$ para os frutos armazenados nas embalagens plásticas, na presença do sachê adsorvedor, somente ocorreram aos 30 dias de AR, mantendo-se inalteradas também aos 35 dias de AR. Dessa forma, verificou-se o efeito benéfico do sachê na inibição da ação do etileno e, consequentemente, retardando a senescência desses frutos. Comportamento intermediário e mais promissor do que nos frutos-controle foi observado nos frutos embalados em PEBD e naqueles submetidos somente ao vácuo. Assim, pelo efeito da embalagem e da refrigeração, pode- se retardar em 5 dias o pico climatérico desses frutos, somente observado aos 25 dias de AR. Nesse sentido, a seleção do filme plástico que resultou na AM favorável deve ser baseada na taxa respiratória e nas concentrações ótimas de $\mathrm{O}_{2} \mathrm{e}$ $\mathrm{CO}_{2}$ para o produto (SILVA et al., 2006).

A concentração de etileno livre no interior das embalagens (Figura $3 b$ ) esteve ligada ao efeito da AM e do sachê adsorvedor, e, ainda, ao estádio fisiológico da banana, condicionado também pelo atraso no pico climatérico dos frutos. Dessa forma, acredita-se que a concentração de etileno encontrada no interior das embalagens deveu-se ao reflexo do $\mathrm{CO}_{2}$ produzido (Figura 3a) e ainda à própria senescência dos frutos embalados e submetidos ao sachê adsorvedor. Fator esse determinante para a menor atividade metabólica durante o experimento, comprovada pela menor e mais lenta elevação nos teores de SS (Figura 7), bem como a redução e o retardamento da máxima atividade enzimática (Figuras $5 \mathrm{a}$ e 5b). Observou-se, ainda, que as menores concentrações de etileno foram detectadas no interior das embalagens de PEBD quando acondicionadas com o sachê adsorvedor. Portanto, pode-se inferir sobre a relação fisiológica entre a diminuição dos níveis de etileno livre (Figura 3b) e a diminuição na velocidade meta- bólica dos frutos. O mesmo foi relatado por Neves et al. (2008), verificando-se o aumento da vida de prateleira de mangas refrigeradas com a presença do sachê adsorvedor de etileno. No presente experimento, o uso do sachê adsorvedor, possivelmente, tenha proporcionado a oxidação do etileno liberado pelo fruto durante $o$ amadurecimento, prolongando a fase pré-climatérica e a vida pós-colheita. Neste sentido, Brackmann et al. (2006) concluíram que a adsorção do etileno também manteve a melhor qualidade de bananas 'Prata', tanto no armazenamento a $25^{\circ} \mathrm{C}$ como a $12{ }^{\circ} \mathrm{C}$, sendo o principal fator responsável pela diminuição na velocidade do amadurecimento. Porém, o efeito foi potencializado em concentrações elevadas de $\mathrm{CO}_{2}$, quando os frutos foram armazenados em AM. Neste trabalho, as bananas 'Prata-Anã' puderam ser armazenadas em AM durante 14 e 21 dias, a $25^{\circ} \mathrm{C}$ e $12{ }^{\circ} \mathrm{C}$, respectivamente, sempre com adsorção do etileno. Contudo, no presente experimento, utilizando-se do AR e da AM, e do sistema de adsorção de etileno, a longevidade alcançada com bananas 'Prata-Anã' foi de, no mínimo, 30 dias, o que pode ser entendido como satisfatório, levando-se em consideração que o tempo médio decorrido entre a colheita e a comercialização das bananas em Roraima é de aproximadamente 5 dias.

Com o passar do período de AR, todos os frutos apresentaram incrementos no teor de AT (Figura 4), o que pode ser considerado normal, segundo Nascimento Júnior et al. (2008). Porém, esse incremento foi mais intensificado naqueles frutos onde não houve o controle da ação do etileno. Nos frutos submetidos ao sachê adsorvedor, independentemente do vácuo, somente se observaram incrementos significativos nos teores de AT após o $15^{\circ}$ dia de AR. Também pôde constatar-se que os menores picos de AT ao final do período experimental ocorreram justamente nesses frutos, condicionados, possivelmente, pelas menores quantidades de etileno livre no interior dessas embalagens (Figura 3b). Por outro lado, dos 5 aos 20 dias de AR, os maiores teores de AT foram detectados nos frutos embalados sem o sachê adsorvedor. Tal comportamento atribuiu-se ao fato de a embalagem funcionar como uma membrana que reteve o etileno concentrado junto aos frutos (Figura 3b), fazendo com que o processo de maturação dos mesmos não fosse retardado, confirmando os maiores teores de SS (Figura 7) e a rápida diminuição dos teores de amido desses frutos (Figura 8), assim como a aceleração da atividade enzimática da PME e PG também foi observada após os 15 dias de AR (Figura 5a e 5b).

A partir dos 25 dias de AR, verificaram-se os menores teores de AT nos frutos submetidos à 
presença do sachê adsorvedor combinado ao vácuo. Dessa forma, esses frutos apresentaram-se em estádios de maturação menos avançados que os demais, evoluindo durante o amadurecimento, porém de forma mais lenta, o que permite pressupor para os mesmos maior longevidade pós-colheita.

O comportamento da PME (Figura 5a) pôde ser considerado como semelhante ao da PG (Figura $5 b$ ), por apresentar 2 picos de atividade concomitantes, respectivamente, para cada tratamento realizado. Melo e Vilas Boas (2007) também observaram 2 picos de atividade enzimática durante a maturação de bananas 'Prata-Anã'. Desse modo, foi possível constatar 2 picos sequenciais de atividade enzimática, tanto para PME quanto para PG, porém em diferentes tempos de AR. Nesse sentido, para os frutos do tratamento sem a embalagem plástica, o $1^{\circ}$ e o $2^{\circ}$ picos ocorreram aos 15 e 25 dias de AR, respectivamente. Nos frutos embalados sem o sachê adsorvedor, o $1^{\circ}$ e o $2^{\circ}$ picos de atividade enzimática ocorreram aos 20 e 30 dias, respectivamente. Para os frutos dos tratamentos onde foi utilizado o sachê adsorvedor, os 2 picos de máximo ocorreram aos 25 e 35 dias de experimento. Sendo assim, pôde-se observar que o comportamento dos frutos foi semelhante, mas que a velocidade de início da atividade enzimática se deu de forma mais acelerada nos frutos não embalados. E que, dentre os frutos acondicionados em PEBD, foi maior a velocidade metabólica enzimática nas bananas não submetidas ao sachê adsorvedor de etileno. Sendo assim, pressupõe-se que a atividade enzimática contribuiu e/ou participou das mudanças metabólicas e físico-químicas dos frutos.

Melo e Vilas Boas (2007), realizando trabalho sobre as características pós-colheita de bananas, afirmaram que a PME atua nas pectinas promovendo a desmetilação parcial dos ésteres dos ácidos poligalacturônicos, facilitando o acesso da PG, que determina a despolimerização e a solubilização das substâncias pécticas. Da mesma forma, Melo e Vilas Boas (2007) afirmaram que a PG atua na despolimerização dos polímeros de ácido galacturônico. Ou seja, assim como observado neste trabalho, esses autores revelaram que a PG depende da atividade normal da PME para que se dê prosseguimento ao processo natural de despolimerização dos componentes pécticos da parede celular. No presente trabalho, observou-se que os tratamentos executados determinaram o retardamento das etapas que antecederam e desencadearam a ação de mecanismos enzimáticos. Esse fato foi observado nos frutos embalados e submetidos à ação do adsorvedor de etileno, independentemente do vácuo.

O comportamento dos frutos também demonstrou a ação tecnológica do sachê adsorvedor quanto à atividade da PME e da PG. Ou seja, verificou-se o pico de atividade, seguido de redução e posterior novo pico, o que, quando em comparação ao pico climatérico (Figura 3a), verificou-se que o mesmo antecede o $1^{\circ}$ pico de atividade enzimática. Dessa forma, como o pico climatérico dos frutos dos tratamentos com a presença do sachê adsorvedor foi atrasado, verificou-se o efeito positivo do sachê adsorvedor também na desaceleração da atividade metabólica das enzimas PME e PG. Da mesma maneira, a desaceleração da atividade enzimática nos frutos submetidos ao controle de etileno deveu-se á sequência de eventos metabólicos, dos quais participaram a PG e a PME, sendo igualmente retardados pela menor disponibilidade de etileno (Figura 3b) para dar o impulso no metabolismo do amadurecimento.

Observou-se o decréscimo gradual e progressivo, até os 35 dias, dos teores de pectina total (Figura 6a) no decorrer do experimento. Entretanto, pôde-se constatar que, nos frutos embalados e acondicionados junto ao sachê adsorvedor de etileno, esses teores de pectina total mantiveram-se superiores aos demais tratamentos já a partir dos 20 dias de AR.Neste ponto,observaram-se as primeiras diferenças estatísticas em relação ao tempo e entre os tratamentos. Desse momento em diante, os frutos do tratamento-controle apresentaram os menores teores de pectina total, possivelmente, pelo acelerado metabolismo respiratório, também visualizado nas Figuras $3 a$ e $3 b$. Associou-se esse padrão ao efeito dos tratamentos, em especial nos frutos embalados e submetidos ao sachê adsorvedor de etileno, tendo como resultado o prolongamento temporal das melhores condições da qualidade sensorial. Isso pode ser exemplificado observando a redução dos SS (Figura 7), na redução da velocidade e no atraso do início da atividade enzimática (Figura 5a e 5b).

A solubilização da pectina (Figura $6 \mathrm{~b}$ ) foi atribuída à ação das enzimas PME e PG (Figura 6a e 6b), sendo que outras enzimas, tais como a b-galactosidase, b-1,4 glicanase ou celulase, também podem ter provocado a quebra dos polímeros pécticos (SALES et al., 2004). Neste caso, os compostos pécticos, inicialmente insolúveis, tornaram-se solúveis, pois as pectinas nos frutos encontram-se sob diferentes formas, dependendo do grau de maturidade. Dessa forma, ao contrário do observado nos teores de pectina total, verificou-se que a concentração de pectina solúvel apresentou comportamentos distintos de elevação e queda em função do padrão respiratório de cada fruto, supostamente modificado em função dos tratamentos propostos. Assim, pôde-se verificar o efeito positivo das embalagens plásticas às bananas já aos 10 dias de avaliação, pois os maiores teores 
de pectina solúvel, nesse ponto, foram encontrados nos frutos do tratamento-controle, demonstrando a intensidade metabólica nesses frutos. Resultado semelhante foi observado no $15^{\circ}$ dia de experimento. Porém, as diferenças foram mais visíveis entre os frutos acondicionados com o sachê adsorvedor de etileno. Nesse sentido, os menores teores de pectina solúveis foram encontrados naqueles frutos onde o sachê adsorvedor exercia o efeito na diminuição da velocidade metabólica. Esse comportamento repetiu-se também aos 20 dias de AR. O contrário foi observado aos 25; 30 e 35 dias, onde os maiores teores de pectinas solúveis se concentraram nos frutos tratados com a presença do sachê adsorvedor, justamente por esses tratamentos proporcionarem o retardamento na utilização desse substrato respiratório durante 0 amadurecimento de bananas 'Prata-Anã'.

Com a evolução do período de AR, verificou-se a evolução de solubilização dos componentes químicos sólidos, ou seja, dos SS (Figura 7), pela desnaturação de estruturas moleculares, como a pectina (Figura 6a) ocasionada, supostamente, pelo aumento da atividade enzimática (Figuras 5a e 5b), as quais estão naturalmente presentes nos frutos imaturos. Essas modificações bioquímicas foram desencadeadas a partir da intensificação da respiração, como visualizado na Figura 3a, caracterizada pelo pico climáterico. Assim, na Figura 7, aos 5 dias, verificou-se efeito positivo da ação do sachê adsorvedor de etileno, pois os maiores teores de SS foram encontrados nos frutos expostos aos tratamentos sem o sachê adsorvedor de etileno. Tal efeito deveu-se à maior concentração de etileno livre no interior das embalagens (Figura 3b), visto que a ausência do sachê adsorvedor fez com que o processo de amadurecimento se desenvolvesse de modo natural, mantendo-se normal a velocidade do metabolismo do fruto. Esse comportamento tornou-se mais marcante a partir dos 20 dias de AR entre os frutos embalados a vácuo, naqueles submetidos somente ao adsorverdor e naqueles onde foi utilizado o sachê adsorvedor e vácuo. Ao final, os frutos embalados em filmes plásticos de PEBD com a presença do adsorvedor de etileno e a utilização do vácuo apresentaram os melhores resultados quanto à manutenção nos teores de SS ao final do experimento. Entretanto, observou-se que, nos frutos do tratamento-controle, pela própria condição de plena senescência, os teores de SS estabilizaram-se e começaram a decrescer, como resposta química a sua utilização como susbtrato respiratório durante essa etapa. Dessa maneira, ficou evidenciado que a velocidade desse processo foi influenciada pelos tratamentos executados.

Ao observar-se a Figura 8, verificou-se constante diminuição nos teores de amido, dado pela conversão do amido em açúcares simples (NOGUEIRA et al., 2007). Dentre outras, essa mudança, uma das mais notáveis no amadurecimento das bananas, predominantemente resulta na produção de açúcares redutores, comumente utilizados como susbtratos para a respiração dos frutos. Na fase matura, a porcentagem de amido é reduzida a até $0,5 \%$ (VIVIANE; LEAL, 2007), assim como observado no presente experimento, dos $20 \%$ iniciais, quando os frutos se encontravam ainda verdes. Porém, pode-se constatar, no presente experimento, que a maior manutenção nos teores de amido deu-se nos frutos dos tratamentos onde foi utilizado sachê adsorvedor de etileno. Assim, permite-se afirmar que o efeito do sachê adsorvedor prolongou a manutenção das características joviais dos frutos, visto que, num mesmo período de tempo, esses frutos apresentavam os maiores teores de amido (Figura 8), de AT (Figura 4) e os menores teores de SS (Figura 7).

Quanto à influência da temperatura, Martins et al. (2007), realizando experimento com bananas 'Prata-Anã', concluíram que os frutos armazenados a 10 e $12{ }^{\circ} \mathrm{C}$, por 35 dias, apresentaram teores de amido semelhantes entre si, embora inferiores aos dos frutos recém-colhidos, o que comprova a degradação do amido durante o amadurecimento. Assim, pôde-se inferir que, além dos tratamentos executados, o AR também contribuiu para todos os tratamentos na redução da velocidade dos incrementos nos teores de SS (Figura 8), coerentes com a degradação dos teores de amido (Figura 8). Contudo, essas transformações não foram evitadas, e sim retardadas, principalmente para os frutos embalados com o sachê adsorvedor de etileno. Portanto, essas transformações, apesar de mais lentas, são consideradas importantes durante o amadurecimento das bananas, sendo diretamente responsáveis por modificações desejáveis no sabor e textura dos frutos. 
PERDADE MASSA FRESCA

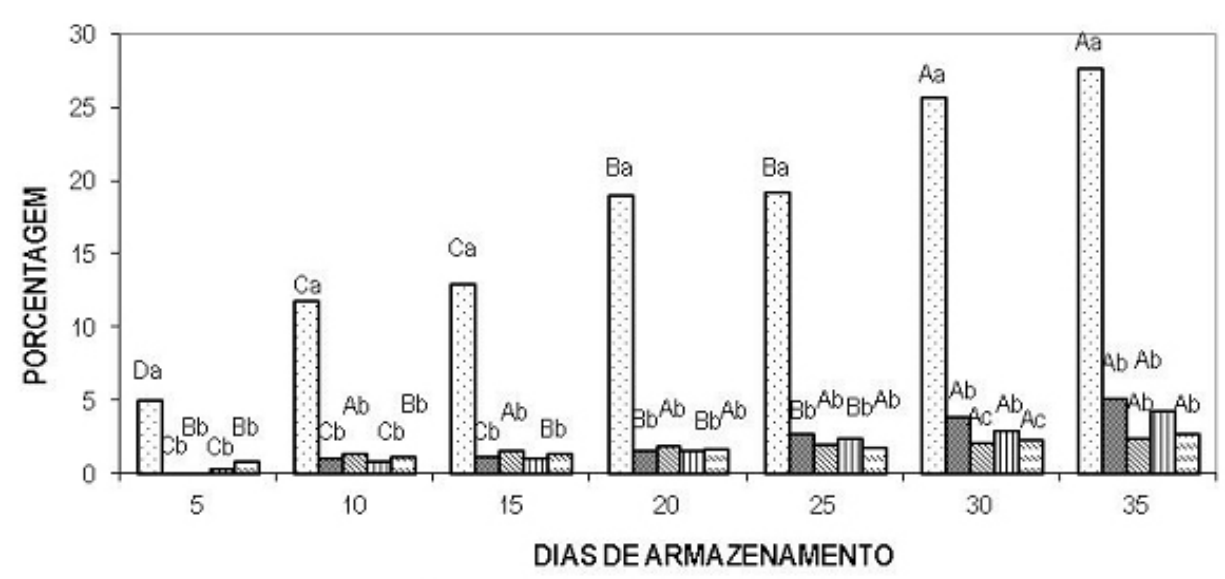

CV medio da interaça: 6,12

D.M.S. media da interação: 1,3812

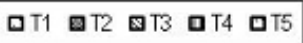

FIGURA 1 - Perda de massa fresca em bananas 'Prata-Anã' quando submetidas a diferentes tratamentos: T1 - Controle; T2 - Embalagem de polietileno de baixa densidade (PEBD); T3 - Embalagem de PEBD + adsorvedor de etileno; T4 - Embalagem de PEBD + vácuo; e T5 - Embalagem de PEBD + adsorvedor de etileno + vácuo. As médias seguidas das mesmas letras, maiúsculas nos dias de armazenamento e minúsculas entre os tratamentos, não diferem entre si, ao nível de $5 \%$ de probabilidade (Tukey).

\section{COLORAÇÄO}

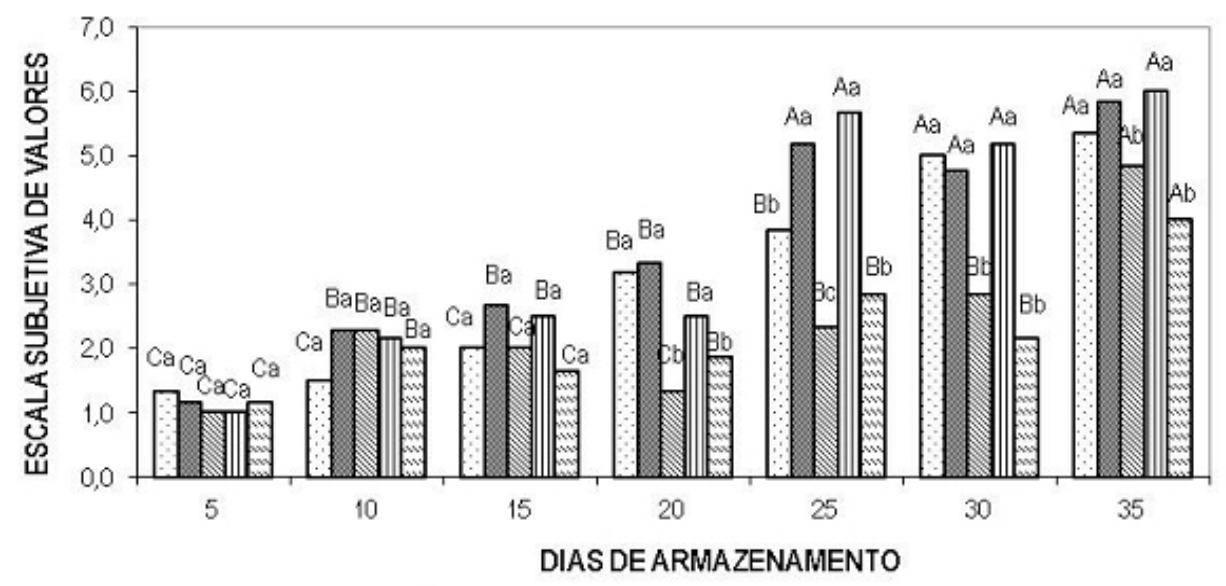

CV medio da interaçã̃o: 4,90

D.M.S. media da interaçắo: 1,1220

口T1 घT2 ब

FIGURA 2 - Coloração em bananas 'Prata-Anã' quando submetidas a diferentes tratamentos: T1 - Controle; T2 - Embalagem de polietileno de baixa densidade (PEBD); T3 - Embalagem de PEBD + adsorvedor de etileno; T4 - Embalagem de PEBD + vácuo; e T5 - Embalagem de PEBD + adsorvedor de etileno + vácuo. As médias seguidas das mesmas letras, maiúsculas nos dias de armazenamento e minúsculas entre os tratamentos, não diferem entre si, ao nível de 5\% de probabilidade (Tukey). 


\section{CONCENTRAÇÄODE CO2}

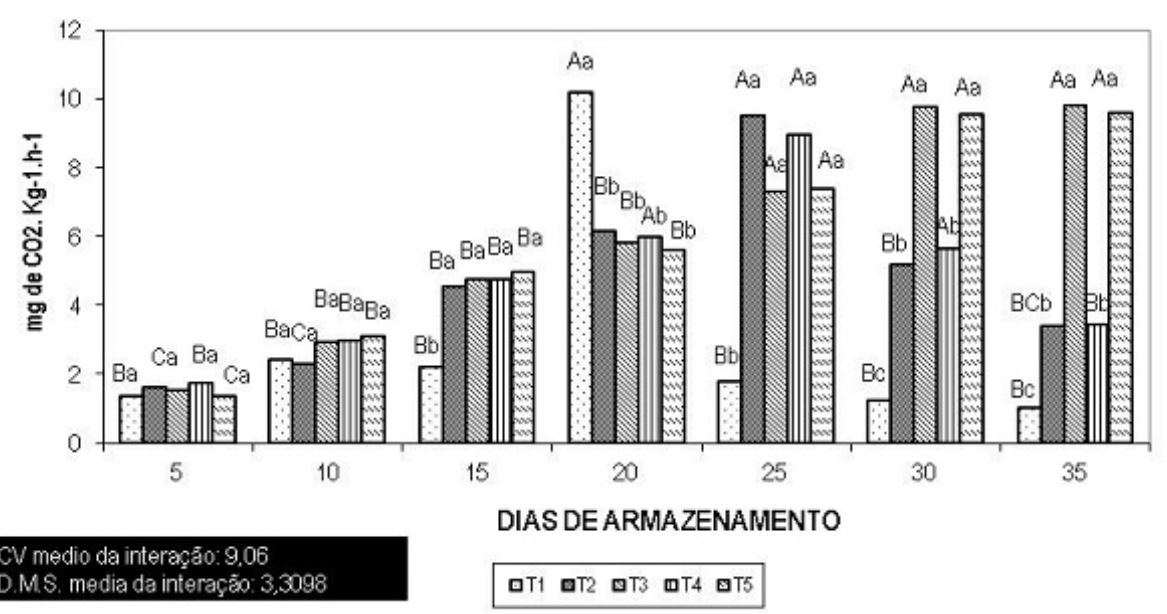

FIGURA 3A - Concentração de $\mathrm{CO}_{2}$ em bananas 'Prata-Anã' quando submetidas a diferentes tratamentos: T1 - Controle; T2 - Embalagem de polietileno de baixa densidade (PEBD); T3 - Embalagem de PEBD + adsorvedor de etileno; T4 - Embalagem de PEBD + vácuo; e T5 - Embalagem de PEBD + adsorvedor de etileno + vácuo. As médias seguidas das mesmas letras,maiúsculas nos dias de armazenamento e minúsculas entre os tratamentos, não diferem entre si, ao nível de $5 \%$ de probabilidade (Tukey).

\section{Concentração de etileno}

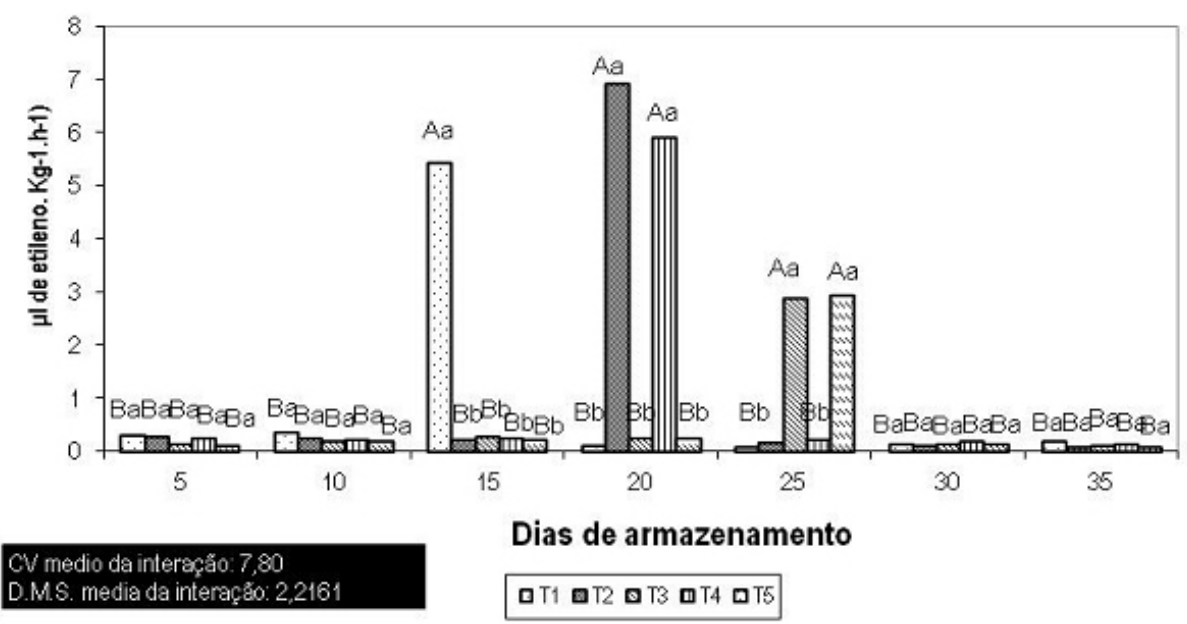

FIGURA 3B - Concentração de etileno em bananas 'Prata-Anã' quando submetidas a diferentes tratamentos: T1 - Controle; T2 - Embalagem de polietileno de baixa densidade (PEBD); T3 - Embalagem de PEBD + adsorvedor de etileno; T4 - Embalagem de PEBD + vácuo; e T5 - Embalagem de PEBD + adsorvedor de etileno + vácuo. As médias seguidas das mesmas letras, maiúsculas nos dias de armazenamento e minúsculas entre os tratamentos, não diferem entre si, ao nível de $5 \%$ de probabilidade (Tukey). 


\section{Acidez titulável}

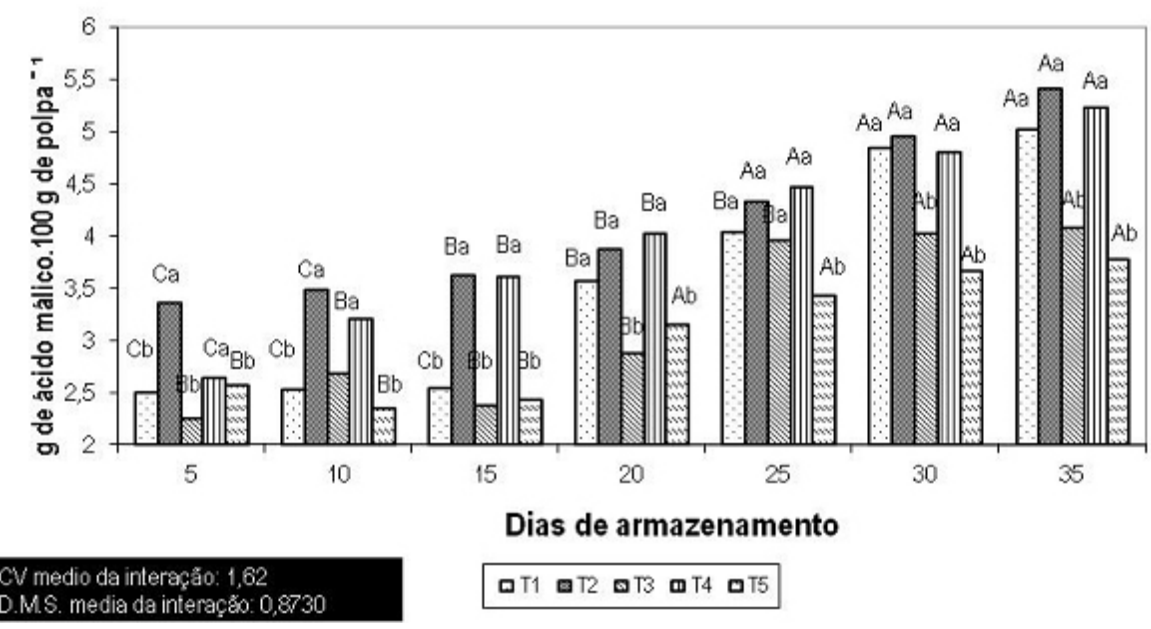

FIGURA 4 - Acidez titlável em bananas 'Prata-Anã' quando submetidas a diferentes tratamentos: T1 Controle; T2 - Embalagem de polietileno de baixa densidade (PEBD); T3 - Embalagem de PEBD + adsorvedor de etileno; T4 - Embalagem de PEBD + vácuo; e T5 - Embalagem de PEBD + adsorvedor de etileno + vácuo. As médias seguidas das mesmas letras, maiúsculas nos dias de armazenamento e minúsculas entre os tratamentos, não diferem entre si, ao nível de $5 \%$ de probabilidade (Tukey).

\section{ATIVIDADE DA PECTINAMETILESTERASE}

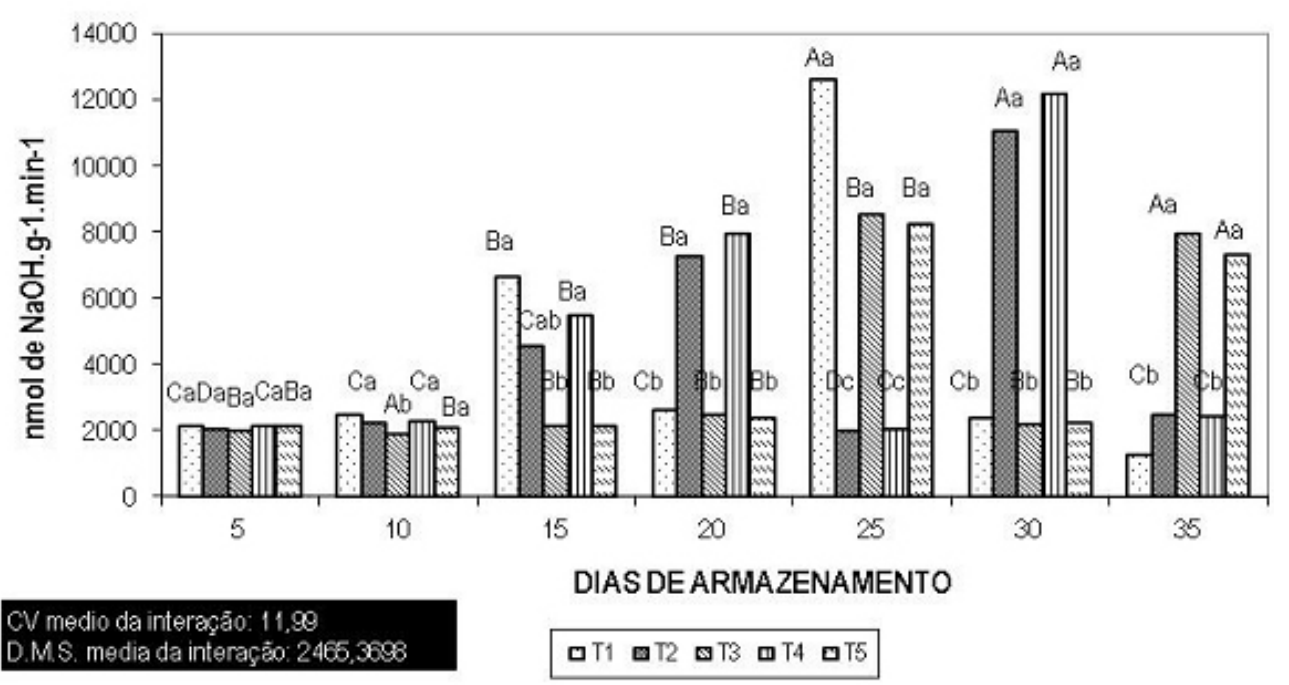

FIGURA 5A - Atividade da pectinametilesterase em bananas 'Prata-Anã' quando submetidas a diferentes tratamentos: T1 - Controle; T2 - Embalagem de polietileno de baixa densidade (PEBD); T3 - Embalagem de PEBD + adsorvedor de etileno; T4 - Embalagem de PEBD + vácuo; e T5 - Embalagem de PEBD + adsorvedor de etileno + vácuo. As médias seguidas das mesmas letras, maiúsculas nos dias de armazenamento e minúsculas entre os tratamentos, não diferem entre si, ao nível de $5 \%$ de probabilidade (Tukey). 


\section{ATIVIDADE DAPECTINAMETILESTERASE}

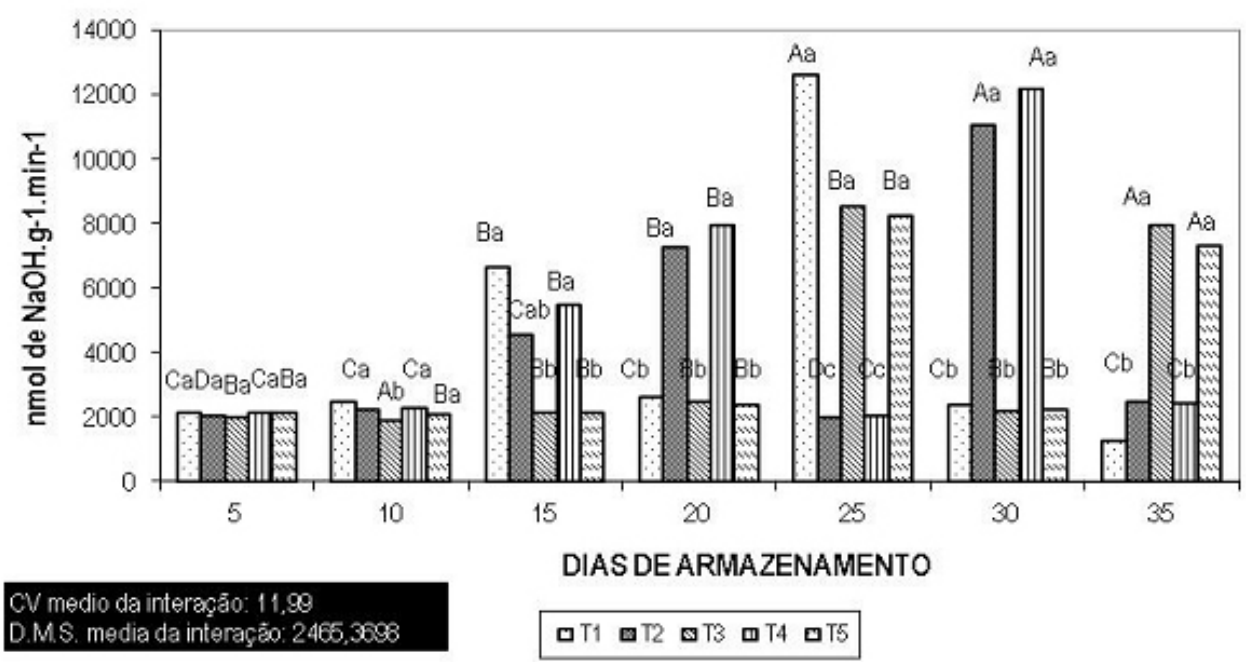

FIGURA 5B - Atividade da poligalacturonase em bananas 'Prata-Anã' quando submetidas a diferentes tratamentos: T1 - Controle; T2 - Embalagem de polietileno de baixa densidade (PEBD); T3 - Embalagem de PEBD + adsorvedor de etileno; T4 - Embalagem de PEBD + vácuo; e T5 - Embalagem de PEBD + adsorvedor de etileno + vácuo. As médias seguidas das mesmas letras, maiúsculas nos dias de armazenamento e minúsculas entre os tratamentos, não diferem entre si, ao nível de $5 \%$ de probabilidade (Tukey).

PECTINA TOTAL

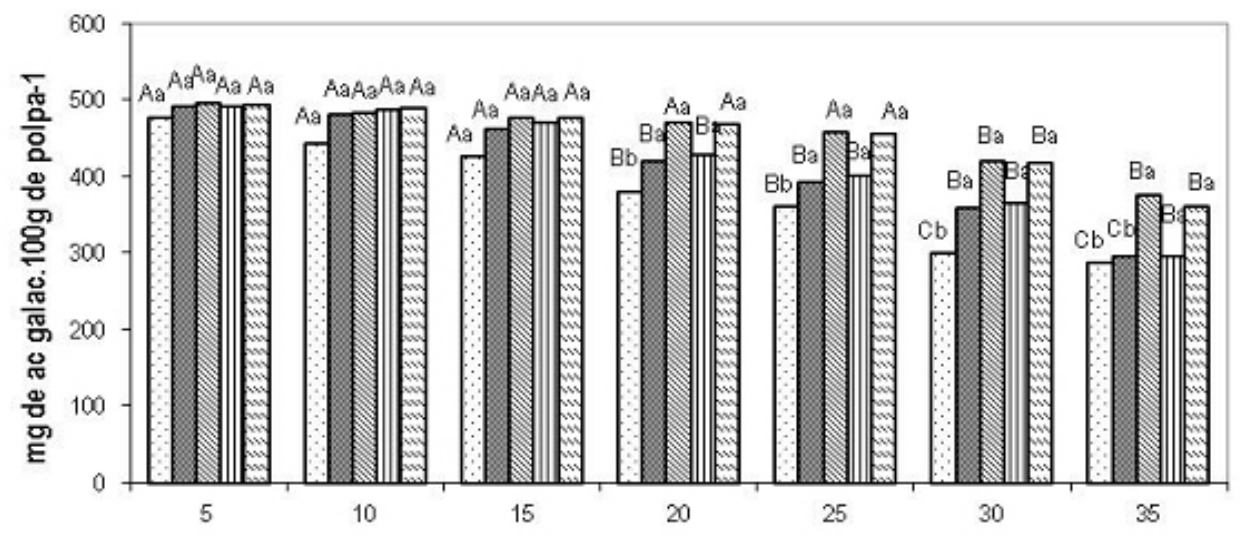

CV medio da intereção: 12,05

D.M.S. media da interaçz: 62,2366

DIAS DE ARMAZENAMENTO

FIGURA 6A - Pectina total em bananas 'Prata-Anã' quando submetidas a diferentes tratamentos: T1 Controle; T2 - Embalagem de polietileno de baixa densidade (PEBD); T3 - Embalagem de PEBD + adsorvedor de etileno; T4 - Embalagem de PEBD + vácuo; e T5 - Embalagem de PEBD + adsorvedor de etileno + vácuo. As médias seguidas das mesmas letras, maiúsculas nos dias de armazenamento e minúsculas entre os tratamentos, não diferem entre si, ao nível de $5 \%$ de probabilidade (Tukey). 


\section{PECTINA SOLÚVEL}

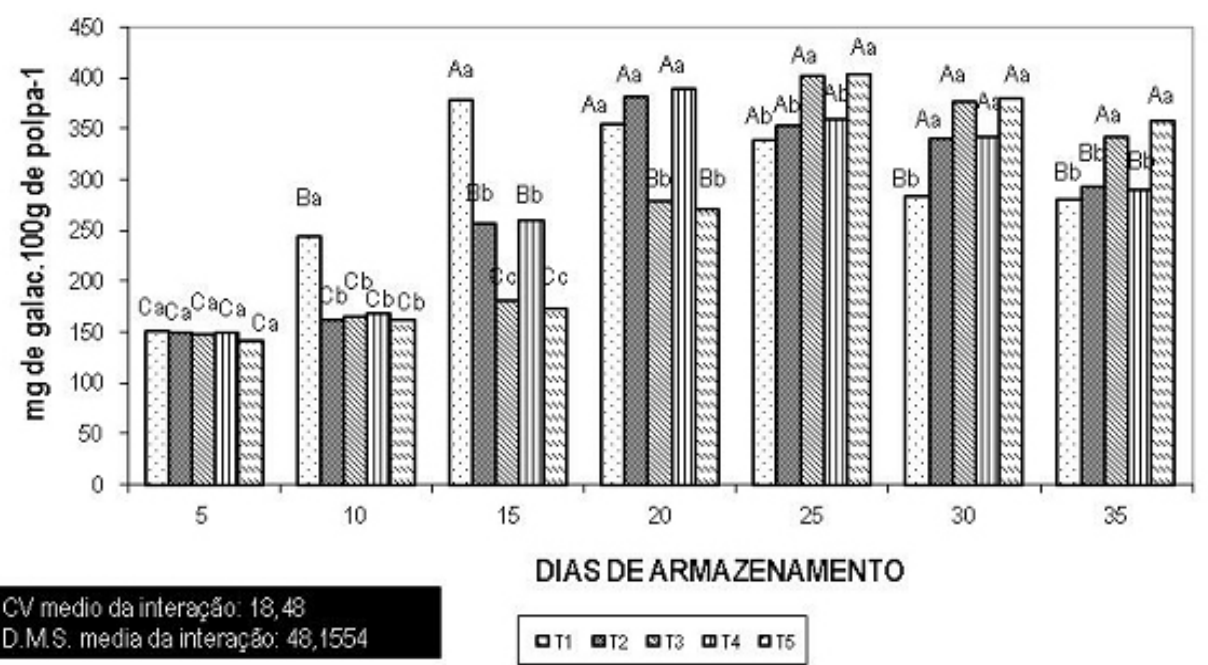

FIGURA 6B - Pectina solúvel em bananas 'Prata-Anã' quando submetidas a diferentes tratamentos: T1 Controle; T2 - Embalagem de polietileno de baixa densidade (PEBD); T3 - Embalagem de PEBD + adsorvedor de etileno; T4 - Embalagem de PEBD + vácuo; e T5 - Embalagem de PEBD + adsorvedor de etileno + vácuo. As médias seguidas das mesmas letras, maiúsculas nos dias de armazenamento e minúsculas entre os tratamentos, não diferem entre si, ao nível de $5 \%$ de probabilidade (Tukey).

\section{SÓLIDOS SOLÚVEIS}
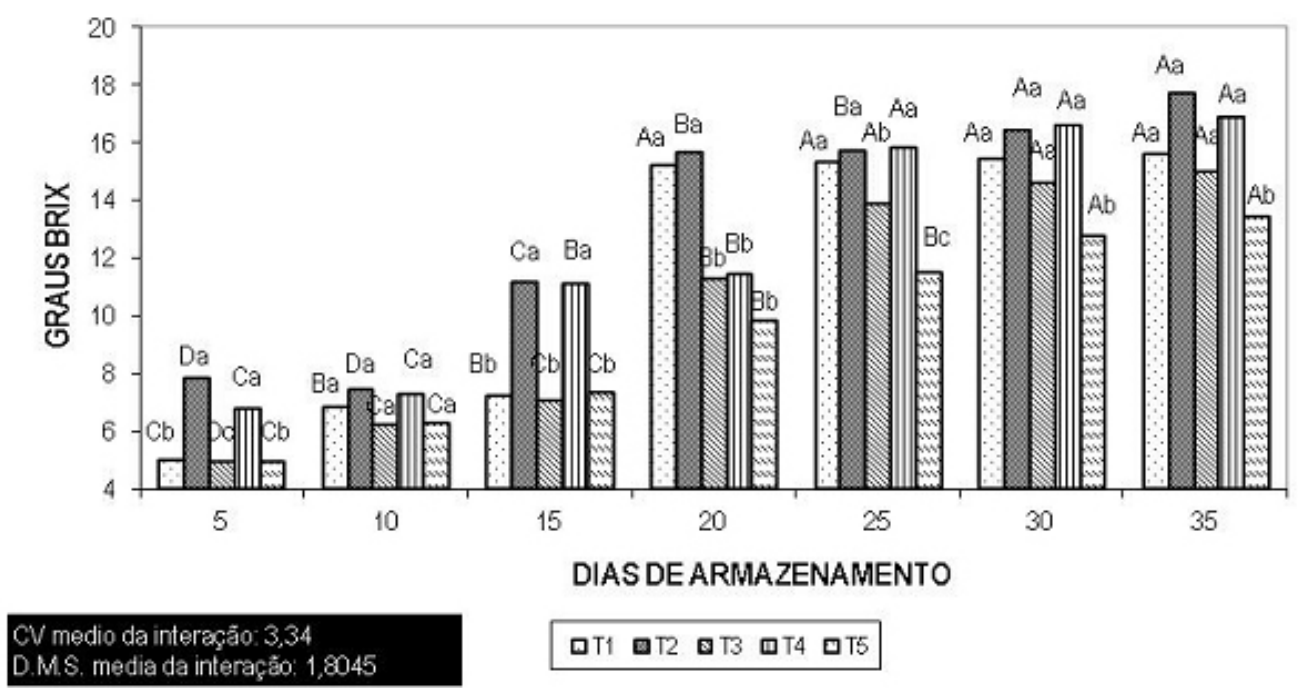

ロ

FIGURA 7 - Sólidos solúveis em bananas 'Prata-Anã' quando submetidas a diferentes tratamentos: T1 Controle; T2 - Embalagem de polietileno de baixa densidade (PEBD); T3 - Embalagem de PEBD + adsorvedor de etileno; T4 - Embalagem de PEBD + vácuo; e T5 - Embalagem de PEBD + adsorvedor de etileno + vácuo. As médias seguidas das mesmas letras, maiúsculas nos dias de armazenamento e minúsculas entre os tratamentos, não diferem entre si, ao nível de $5 \%$ de probabilidade (Tukey). 


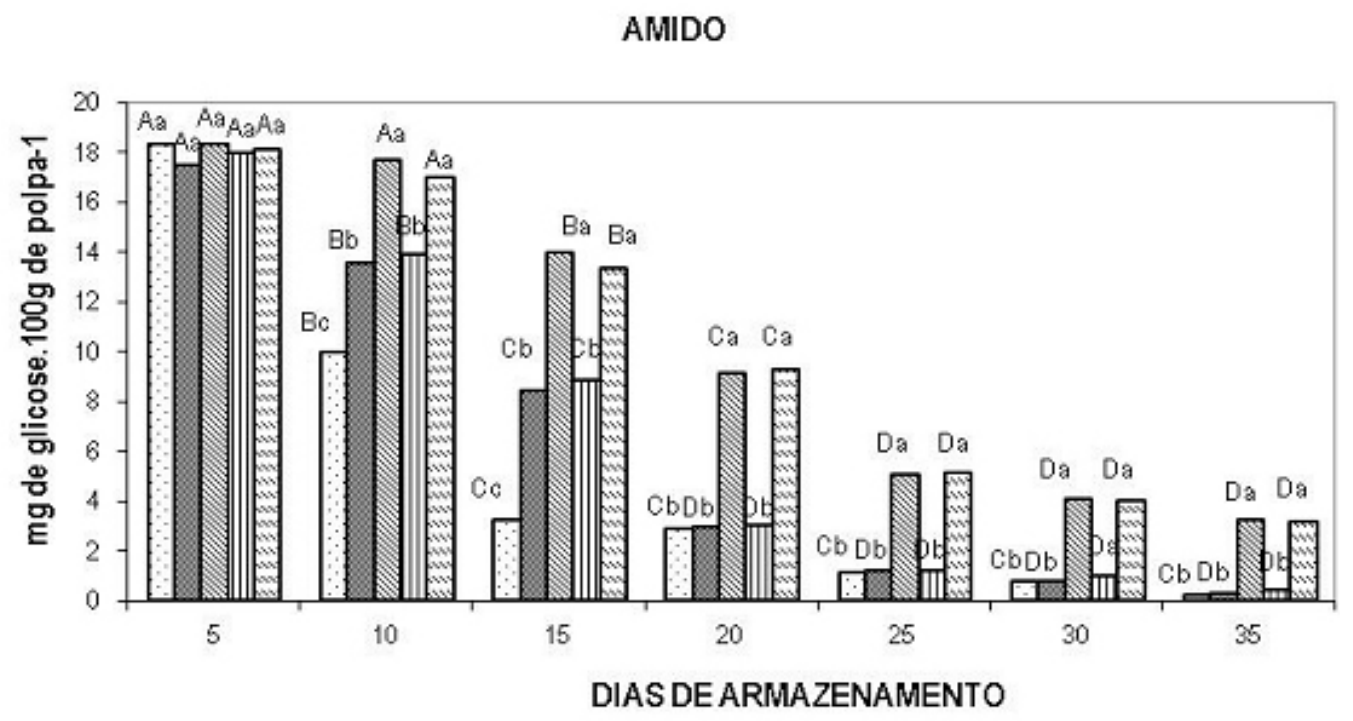

CV medio da interação: 7,96

D.M.S. media da interaçéc: 2,9736

$\begin{array}{lllll}\text { 口T1 } & \text { 日T2 } & \text { घT3 } & \text { ロT4 } & \text { 口T5 }\end{array}$

FIGURA 8 - Amido em bananas 'Prata-Anã' quando submetidas a diferentes tratamentos: T1 - Controle; T2 - Embalagem de polietileno de baixa densidade (PEBD); T3 - Embalagem de PEBD + adsorvedor de etileno; T4 - Embalagem de PEBD + vácuo; e T5 - Embalagem de PEBD + adsorvedor de etileno + vácuo. As médias seguidas das mesmas letras, maiúsculas nos dias de armazenamento e minúsculas entre os tratamentos, não diferem entre si, ao nível de $5 \%$ de probabilidade (Tukey).

\section{CONCLUSÕES}

1-A combinação do uso da embalagem de PEBD com o sachê de permanganato de potássio $\left(\mathrm{KMnO}_{4}\right)$ resultou no retardamento do processo de maturação dos frutos de banana 'Prata-Anã', quando armazenada a $12^{\circ} \mathrm{C}$;

2-Pode-se atribuir esse efeito benéfico à presença do sachê na adsorção de etileno e, consequentemente, na ação do etileno no amadurecimento dos frutos, retardando a senescência das bananas 'Prata-Anã'.

\section{REFERÊNCIAS}

BITTER, T.; MUIR, H. M. A modified uronic acid carbazole reaction. Analytical Chemistry, New York, v. 34, p. 330-334, 1962.

BRACKMANN, A.; STEFFENS， C.; SESTARI,I.; NEUWALD, A.; GIEHL, R. F. H. Armazenamento em atmosfera modificada e controlada de banana 'Prata' com absorção de etileno. Ciência e Agrotecnologia. Lavras, v. 30, n. 5, p. 914-919, 2006.
FINGER, F. L.; PUSCHMANN, R.; BARROS, R. S. Effects of water loss on respiration, ethylene production and ripening of banana fruit. Revista Brasileira de Fisiologia Vegetal, Brasília, v. 7, n.1, p. 95-114, 1995.

IAL - Instituto Adolfo Lutz. Métodos físico-químicos para análise de alimentos. 4.ed. Brasília: ANVISA, 2005.

JEN, J.J.; ROBINSON, M.L.P. Pectolytic enzymes in sweet bell peppers (Capsicum annum L.). Journal of Food Science, Chicago, v.49, n.4, p.1085-1087, 1984

JERÔNIMO, E. M.; BRUNINI, M. A.; ARRUDA, M. C. de; CRUZ, J. C. S.; GAVA, G. J. de C.; SILVA, M. de A. Qualidade de mangas 'Tommy Atkins' armazenadas sob atmosfera modificada. Ciência e Agrotecnologia, Lavras, v. 31, n. 4, p. 1122-1130, 2007. 
MARTINS, R. N.; DIAS, M. S. C.; VILLAS BOAS, E. V. de B.; SANTOS, L. O. Armazenamento refrigerado de banana 'Prata-Anã' proveniente de cachos com 16, 18 e 20 semanas. Ciência e Agrotecnologia, Lavras, v. 31, n. 5, 2007.

McCREADY, R. M.; McCOOMB, E. A. Extraction and determination of total pectic materials in fruits. Analytical Chemistry, Washington, v. 42, n. 12, p. 1586-1588, 1952.

MELO, A. A. M.; VILAS BOAS, E. V. de B. Redução do amaciamento de banana 'Maçã' minimamente processada pelo uso de tratamentos químicos. Ciência e Agrotecnologia, Lavras, v.31, n.3, p. 821-828, 2007

NASCIMENTO JÚNIOR, B. B. do; OZORIO, L. P.; REZENDE, C. M.; SOARES, A. G.; FONSECA, M. J. de O. Diferenças entre bananas de cultivares Prata e Nanicão ao longo do amadurecimento: características físico-químicas e compostos voláteis. Ciência e Tecnologia de Alimentos, Campinas, v. 28, n. 3, p.649-658, 2008.

NEVES, L. C.; BENEDETTE, R. M.; SILVA, V. X.; PRILL, M. A. de S.; ROBERTO, S. R.; VIEITES, R. L. Qualidade pós-colheita de mangas, não refrigeradas, e submetidas ao controle da ação do etileno. Revista Brasileira de Fruticultura, Jaboticabal, v. 30, n. 1, p. 94-100, 2008.

NOGUEIRA, D. H.; PEREIRA, W. E.; SILVA, S. de M.; ARAÚJO, R. da C. Mudanças fisiológicas e químicas em bananas 'Nanica' e 'Pacovan' tratadas com carbureto de cálcio. Revista Brasileira de Fruticultura, Jaboticabal ,v. 29, n. 3, p. 460-464, 2007.

PEREIRA, G. M.; FINGER, F. L.; CASALI, V. W. D.; BROMMONSCHENKEL, S. H. Influência do tratamento com etileno sobre o teor de sólidos solúveis e a cor de pimentas. Bragantia, Campinas, v. 67 , n. 4 , p.1031-1036, 2008

PINTO, L. K. de A.; MARTINS, M. L. L.; RESENDE, E. D. de; ALMEIDA, R. F. de; VITORAZI, L.; PEREIRA, S. M. de F. Influência da atmosfera modificada por filmes plásticos sobre a qualidade do mamão armazenado sob refrigeração. Ciência e Tecnologia de Alimento, Campinas, v. 26, n. 4, p. 744-748, 2006.
PRESSEY, R.; AVANTS, J.K.Separation and characterization of exopolygalacturonase and endopolygalacturonase from peaches. Plant Physiology, Baltimore, v. 52, n. 3, p. 252-256, 1973.

PRILL, M. A. de S.; NEVES, L. T. B. C.; CAMPOS, A. J. de; SILVA, S.; CHAGAS, E. A.;ARAÚJO, W. F. de. Aplicações de tecnologias pós-colheita para bananas 'Prata-Anã' produzidas em Roraima. Revista Brasileira de Engenharia Agrícola e Ambiental, Campina Grande, v.16, n.11, p.1.237-1.242, 2012

SALES, A. N. de; BOTREL, N.; e COELHO, A. H. R. Aplicação de 1-metilciclopropeno em banana 'Prata-Anã' e seu efeito sobre as substâncias pécticas e enzimas pectinolíticas. Ciência e Agrotecnologia, Lavras, v. 28, n. 3, p. 479-487, 2004.

SARMENTO, J. D. A.; MORAIS, P. L. D. de; ALMEIDA, M. L.B.; SILVA, G. G. da; SARMENTO, D. H. A.; BATALHA, S. de A. Qualidade pós-colheita de banana submetida ao cultivo orgânico e convencional. Revista Brasileira de Produtos Agroindustriais, Campina Grande, v.14, n.1, p.85-93, 2012

SILVA, C. de S.; LIMA, L. C.; SANTOS, H. S; CAMILI, E. C.; VIEIRA, C. R. I. Y.; MARTIN, C. da S.; VIEITES, R. L. Amadurecimento da banana-prata climatizada em diferentes dias após a colheita. Ciência e Agrotecnologia, Lavras, v. 30, n. 1, 2006.

SILVA, D. F. P.; SALOMÃO, L. C. C.; SIQUEIRA, D. L. de; CECON, P. R.; ROCHA, A. Potassium permanganate effects in postharvest conservation of the papaya cultivar Sunrise Golden. Pesquisa Agropecuária Brasileira, Brasília, v. 44, n. 7, 669675, 2009.

VON LOESECKE, 1950 consta nas p.4 linha 12; p. 5 linhas 24; p.7 linha 19 